\title{
RESPON PERTUMBUHAN TANAMAN GELOMBANG CINTA AKIBAT PEMBERIAN PUPUK DAUN PETROVITA DI PEMBIBITAN LANJUTAN
}

\author{
DJOKO EKO HADI SUSILO \& SRI HANDAYANI WAHYUNINGSIH \\ Dosen Program Studi Agroteknologi Fakultas Pertanian dan Kehutanan Universitas Muhammadiyah \\ Palangkaraya
}

\begin{abstract}
ABSTRAK
Penelitian ini bertujuan untuk mengetahui respon pertumbuhan tanaman gelombang cinta (Anthurium plowmanii) terhadap pemberian pupuk daun Petrovita di pembibitan lanjutan yang dilaksanakan pada Agustus - Oktober 2011 di Kelurahan Panarung, Kecamatan Pahandut, Kota Palangka Raya. Rancangan perlakuan tunggal (satu faktor) dengan 10 (sepuluh) kali pengulangan berupa pemberian pupuk daun Petrovita (D) yang terdiri dari 5 taraf konsentrasi, yaitu : $\mathrm{d}_{1}=0,5 \mathrm{ml} \mathrm{I}^{-1}(0,05 \%) ; \mathrm{d}_{2}=1,0 \mathrm{ml}^{-1}(0,10 \%)$; $\mathrm{d}_{3}=1,5 \mathrm{ml} \mathrm{I}^{-1}(0,15 \%) ; \mathrm{d}_{4}=2,0 \mathrm{ml} \mathrm{I}^{-1}(0,20 \%) ;$ dan $\mathrm{d}_{5}=2,5 \mathrm{ml} \mathrm{l}^{-1}(0,25 \%)$ menggunakan rancangan lingkungan Rancangan Acak Lengkap. Pengamatan dilakukan saat tanaman di pembibitan lanjutan telah mendapatkan aplikasi perlakuan sebanyak 4 kali dengan interval 2 minggu sekali. Pengamatan dilakukan terhadap tinggi tanaman $(\mathrm{cm})$; tinggi batang $(\mathrm{cm})$; jumlah daun (daun); panjang daun $(\mathrm{cm})$; lebar daun $(\mathrm{cm})$; dan luas daun $\left(\mathrm{cm}^{2}\right)$.

Hasil penelitian ini menunjukkan bahwa pemberian pupuk daun lengkap Petrovita berpengaruh sangat nyata meningkatkan pertumbuhan tanaman gelombang cinta umur 8 MST di pembibitan lanjutan. Pemberian pupuk Petrovita konsentrasi $0,2 \%$ atau $2 \mathrm{ml} \mathrm{l}^{-1}\left(\mathrm{~d}_{4}\right)$ merupakan perlakuan yang terbaik dan efisien terhadap tanaman gelombang cinta di pembibitan lanjutan. Disarankan untuk meningkatkan pertumbuhan tanaman gelombang cinta di pembibitan lanjutan menggunakan Petrovita konsentrasi 0,2\% tetapi dicoba dengan interval pemberiannya kurang dari 2 minggu (misalnya 1 minggu sekali).
\end{abstract}

Kata kunci : pupuk daun, Petrovita, gelombang cinta, Anthurium plowmanii

\section{PENDAHULUAN}

Wirausaha tanaman hias saat ini memiliki prospek yang sangat potensial. Salah satunya terlihat dari semakin banyak bermunculan usaha penyemaian, pembibitan dan pameran tanaman hias. Kondisi ini menunjukan bahwa hobiis tanaman selalu ada dan terus bertambah.

Salah satu tanaman hias yang diminati adalah jenis anthurium gelombang cinta (Anthurium plowmanii) karena keindahan warna, variasi daun berbentuk panjang bergelombang, pemukaanya berwarna hijau mengkilap, urat-urat daun tampak jelas, dan bertangkai pendek. Ketertarikan memiliki tanaman hias membuat permintaannya meningkat dari tahun-ketahun
(Budhiprawira dan Saraswati, 2006 dalam Waryoto, 2009).

Keberadaan tanaman gelombang cinta di Provinsi Kalimantan Tengah masih sedikit dan kurang diminati masyarakat membudidayakannya. Tahun 2008 di Provinsi Kalimantan Tengah masih terdapat 117 tanaman gelombang cinta yang dibudidayakan, sedangkan di Kota Palangka Raya hanya sekitar 10 tanaman (Anonim, 2009). Menurut informasi mayarakat, karena kebutuhan penggunaan masih terbatas sebagai tanaman hias, harganya relatif mahal, dan masih dikembangkan sebagai tanaman hias yang dimiliki beberapa peminat untuk di pekarangan rumah saja dan tidak dibudidayakan secara banyak. Hal 
ini mengakibatkan rendahnya data kepemilikan tanaman gelombang cinta di masyarakat.

Masih rendahnya budidaya tanaman hias tersebut, secara umum terlihat juga dari luasan wilayah Kalimantan Tengah baru digunakan sebesar $18.276 \mathrm{Ha}$ untuk pengembangan komoditas tanaman hias dari total penggunaan seluruh komoditas sebesar 3.546.857 Ha dan sekaligus menunjukkan peluang pengembangan komoditas tanaman pertanian secara luas khususnya budidaya tanaman hortikultura yang didukung potensi wilayah tersebut (Bhermana et al., 2009).

Kendala yang sering terjadi pada budidaya tanaman anthurium gelombang cinta (Anthurium plowmanii) adalah waktu pertumbuhannya yang sangat lambat, penambahan satu helai daun terkadang membutuhkan waktu sekitar 2 minggu, padahal setiap penambahan satu helai daun akan menaikkan harga jualnya, sehinga perlu usaha percepatan pertumbuhan. Usaha untuk mengatasi percepatan pertumbuhan tanaman gelombang cinta dapat dilakukan dengan pemupukan untuk menyediakan/menambah unsur hara yang dibutuhkan oleh tanaman melalui akar dan daun guna mempercepat pertumbuhan (Pranata, 2004 dalam Waryoto, 2009).

Pemberian nutrisi (pupuk) pada tanaman gelombang cinta selain mempercepat pertumbuhannya, juga membantu mempercantik penampilannya. Selain haranya diusahakan mengandung hara makro dan mikro, pupuk yang diberikan harus diperhatikan dosis, konsentrasi dan interval (keseringan) pemberiannya sehingga defisiensi maupun over dosis dapat dihindari dan hal-hal yang fatal tidak terjadi, misalnya daunnya menguning ataupun mati (Anonim, 2007; Anonim,
2008). Unsur makro akan membantu proses pertumbuhan sebagai sumber energi; pembentukan protein, karbohidrat dan antibody; dan membantu proses penyerapan air. Unsur mikro berperan dalam proses pertumbuhan tanaman meskipun dalam jumlah yang sedikit yaitu unsur $\mathrm{Cl}, \mathrm{Fe}, \mathrm{Mn}$, B, dan Cu (Sukamto, 2007 dalam Waryoto, 2009).

Upaya penting dalam mendukung penyediaan hara sekaligus mempercepat pertumbuhan tanaman gelombang cinta di pembibitan lanjutan alternatifnya juga dapat dilakukan melalui daun sebagai pupuk cair lengkap dan mengandung zat tambahan. Pupuk daun cair Petrovita selain telah beredar di pasaran, keuntungannya mengandung unsur hara makro (N, P, K, S, dan $\mathrm{Mg}$ ), dan unsur hara mikro (Fe, Zn, Mo, Mn, Co, B, dan $\mathrm{Cu}$ ), zat penyangga, dan zat pembasah (Anonim, 2010).

Sebagai langkah penyediaan, pemenuhan unsur hara dan mempercepat pertumbuhan tanaman gelombang cinta di pembibitan lanjutan maka pemberian pupuk daun Petrovita dalam diharapkan dapat mengkaji kebutuhan dan upaya penyediaan hara yang efektif bagi tanaman muda gelombang cinta selama pemeliharaan di pembibitan lanjutan.

\section{METODOLOGI}

Penelitian ini dilaksanakan pada bulan Agustus-Oktober 2011 di Kelurahan Panarung, Kecamatan Pahandut, Kota Palangka Raya. Bahan yang digunakan dalam penelitian ini yaitu pupuk daun Petrovita, bibit tanaman gelombang cinta dari pembibitan pendahuluan umur 5 bulan setelah semai, media pakis cacah, dan air. Sedangkan peralatan yang digunakan yaitu cetok, 
pot plastik ukuran sedang $(15 \mathrm{~cm} \times 20 \mathrm{~cm})$, gayung penyiram, pisau cuter, thermometer, handsprayer, kamera, kertas milimeter blok, penggaris, kalkulator, laptop komputer, dan alat tulis.

Rancangan perlakuan tunggal (satu faktor) dengan 10 (sepuluh) kali pengulangan berupa pemberian pupuk daun Petrovita (D) yang terdiri dari 5 taraf konsentrasi, yaitu : $d_{1}=0,5 \mathrm{ml} \mathrm{l}^{-1}$ $(0,05 \%) ; d_{2}=1,0 \mathrm{ml} \mathrm{l}^{-1}(0,10 \%) ; d_{3}=1,5 \mathrm{ml} \mathrm{l}^{-1}$ $(0,15 \%) ; d_{4}=2,0 \mathrm{mll}^{-1}(0,20 \%) ;$ dan $d_{5}=2,5 \mathrm{ml} \mathrm{l}^{-1}$ $(0,25 \%)$ menggunakan rancangan lingkungan Rancangan Acak Lengkap. Pengamatan dilakukan saat tanaman di pembibitan lanjutan telah mendapatkan aplikasi perlakuan sebanyak 4 kali dengan interval 2 minggu sekali. Pengamatan dilakukan terhadap tinggi tanaman $(\mathrm{cm})$; tinggi batang $(\mathrm{cm})$; jumlah daun (daun); panjang daun $(\mathrm{cm})$; lebar daun $(\mathrm{cm})$; dan luas daun $\left(\mathrm{cm}^{2}\right)$ menggunakan metode kertas millimeter (Sitompul dan Guritno, 1995). Data hasil pengamatan dianalisis menggunakan analisis ragam (Uji $F$ ) pada taraf $\alpha=0,05$ dan 0,01 . Uji lanjut yang digunakan adalah uji Beda Nyata Jujur (BNJ) taraf 0,05 (Mattjik dan Sumertajaya, 2002).

\section{HASIL DAN PEMBAHASAN}

\section{Hasil Pengamatan}

Berdasarkan hasil pengamatan dan analisis ragam pertumbuhan tanaman gelombang cinta umur 8 minggu setelah tanam (MST) di pembibitan lanjutan (atau setara bibit berumur 7 bulan setelah semai biji) menunjukkan bahwa pemberian pupuk daun Petrovita berpengaruh sangat nyata terhadap tinggi tanaman, tinggi batang, jumlah daun, panjang daun, lebar daun, dan luas daun. Hasil uji rataan pertumbuhan tanaman gelombang cinta di pembibitan lanjutan disajikan pada Tabel 1.

Berdasarkan Tabel 1. bahwa pengamatan terhadap seluruh peubah respon (tinggi tanaman, tinggi batang, jumlah daun, panjang daun, lebar daun, dan luas daun) menunjukkan kondisi perlakuan $d_{1}$ berbeda nyata dengan perlakuan $d_{2}$ dan $d_{3}$, sedangkan peningkatan konsentrasi sampai perlakuan $d_{4}$ nampaknya berbeda nyata dengan perlakuan yang konsentrasinya lebih rendah $\left(d_{3}, d_{2}\right.$, dan $\left.d_{1}\right)$ namun tidak berbeda nyata dibandingkan dengan perlakuan dengan konsentrasi yang lebih tinggi $\left(d_{5}\right)$. Hanya saja untuk panjang dan lebar daun nampaknya masih sama antara perlakuan $\mathrm{d}_{4}$ dibandingkan dengan $d_{3}$, demikian juga antara perlakuan $d_{4}$ terhadap $d_{5}$ tidak berbeda nyata.

Penyemprotan pupuk Petrovita ini sedemikian rupa menunjukkan bahwa sampai konsentrasi $0,2 \%$ atau $2 \mathrm{ml}^{-1}\left(\mathrm{~d}_{4}\right)$ terbukti mampu meningkatkan pertumbuhan tanaman gelombang cinta, sedangkan peningkatan konsentrasi pemberian sampai $0,25 \%$ atau $2,5 \mathrm{ml}$ $I^{-1} \quad\left(d_{5}\right)$ secara keseluruhan menunjukkan pertumbuhan yang sama dengan perlakuan $d_{4}$ tersebut, meskipun secara kuantitatif tetap menunjukkan peningkatan nilai pertumbuhan seperti Gambar 1, 2 dan 3.

\section{Pembahasan}

Pengaruh sangat nyata perlakuan penyemprotan pupuk daun lengkap Petrovita terhadap tanaman gelombang cinta sampai umur 8 MST di pembibitan lanjutan (Tabel 1) menunjukkan bahwa secara nyata dan efektif terjadi penyediaan hara makro dan mikro bagi 
Tabel 1. Hasil uji rataan pengaruh pemberian pupuk daun Petrovita terhadap pertumbuhan tanaman gelombang cinta umur 8 MST di pembibitan lanjutan

\begin{tabular}{|c|c|c|c|c|c|c|}
\hline \multirow{2}{*}{ Pengamatan } & \multicolumn{5}{|c|}{ Pupuk Daun Petrovita } & \multirow{2}{*}{$\mathrm{BNJ}_{5 \%}$} \\
\hline & $d_{1}$ & $\mathrm{~d}_{2}$ & $\mathrm{~d}_{3}$ & $\mathrm{~d}_{4}$ & $d_{5}$ & \\
\hline a. Tinggi tanaman $(\mathrm{cm})$ & $14,32^{a}$ & $15,90^{b}$ & $21,12^{c}$ & $22,94^{d}$ & $23,91^{d}$ & 1,16 \\
\hline b. Tinggi batang $(\mathrm{cm})$ & $2,79^{a}$ & $3,15^{b}$ & $3,20^{b}$ & $4,39^{c}$ & $4,64^{c}$ & 0,28 \\
\hline c. Jumlah daun (daun) & $8,50^{a}$ & $9,90^{b}$ & $9,80^{b}$ & $14,20^{c}$ & $14,30^{c}$ & 1,21 \\
\hline d. Panjang daun $(\mathrm{cm})$ & $7,05^{\mathrm{a}}$ & $7,12^{a}$ & $8,61^{b}$ & $8,73^{b}$ & $9,29^{b}$ & 0,70 \\
\hline e. Lebar daun $(\mathrm{cm})$ & $2,04^{a}$ & $2,42^{b}$ & $2,69^{\mathrm{C}}$ & $2,74^{\mathrm{c}}$ & $2,82^{c}$ & 0,25 \\
\hline f. Luas daun $\left(\mathrm{cm}^{2}\right)$ & $73,01^{a}$ & $88,66^{b}$ & $132,36^{c}$ & $198,36^{d}$ & $205,75^{d}$ & 7,60 \\
\hline
\end{tabular}

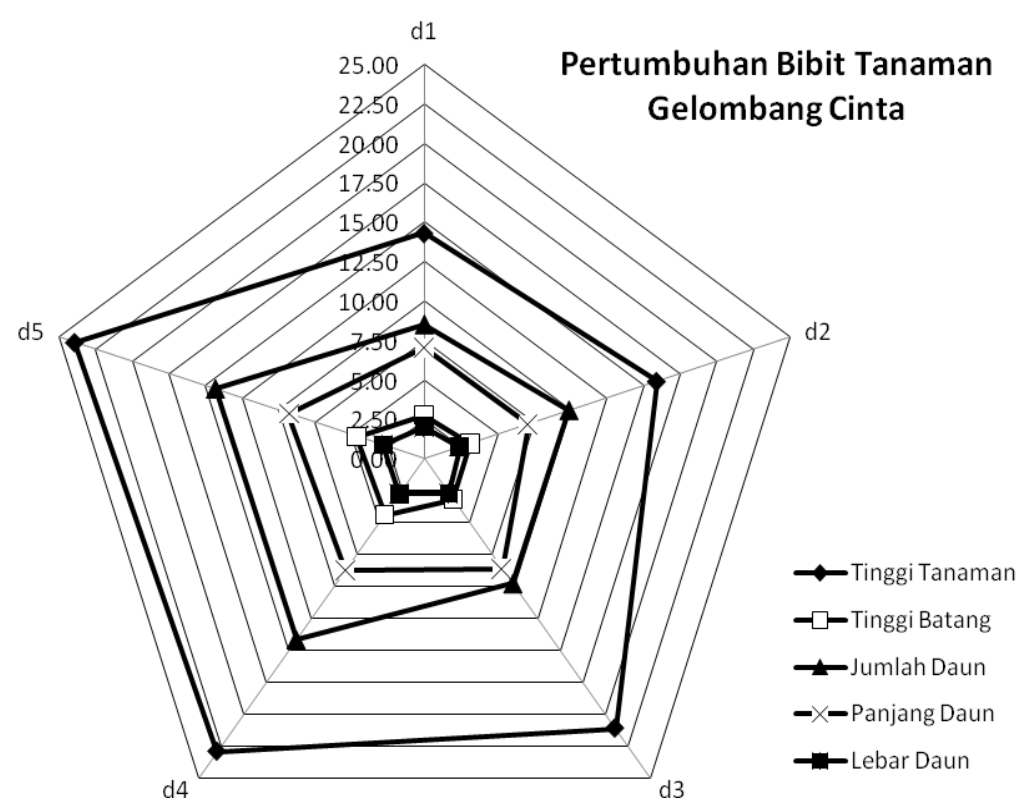

Gambar 1. Kondisi pola kuantitatif pertumbuhan tinggi tanaman, tinggi batang, jumlah daun, panjang daun, dan lebar daun tanaman gelombang cinta umur 8 MST di pembibitan lanjutan.

tanaman dengan melakukan penyemprotan pupuk tersebut. Penyediaan hara pada semua perlakuan direspon dengan baik oleh tanaman gelombang cinta khususnya dalam meningkatkan tinggi tanaman, tinggi batang, jumlah daun, dan luas daun. Sedangkan diantara konsentrasi perlakuan yang diberikan tersebut nampaknya perlakuan $d_{4}$ (konsentrasi $\quad 0,2 \% \quad$ Petrovita) merupakan perlakuan yang terbaik dan efisien untuk diberikan karena berbeda nyata dan mampu meningkatkan pertumbuhan tanaman dibandingkan perlakuan yang lainnya $\left(d_{1}, d_{2}\right.$, dan $\left.d_{3}\right)$ meskipun tiak berbeda nyata dengan perlakuan konsentrasi $0,25 \%\left(d_{5}\right)$.

Peningkatan pertumbuhan tanaman gelombang cinta sampai umur 8 MST di pembibitan lanjutan, dikarenakan pemberian pupuk daun Petrovita berbagai konsentrasi yang 


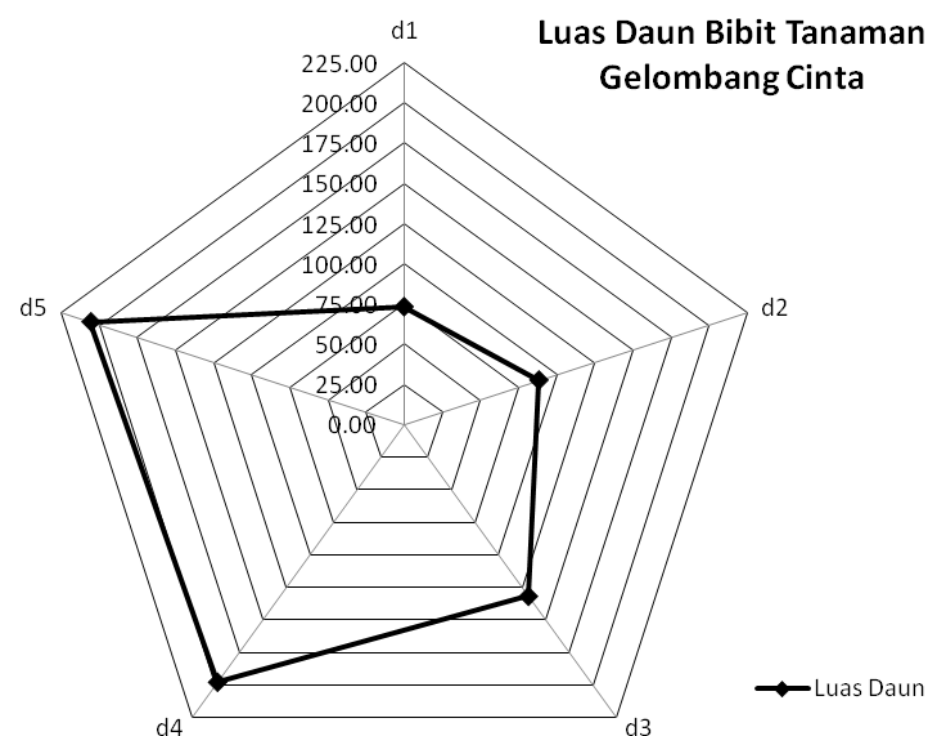

Gambar 2. Kondisi pola kuantitatif pertumbuhan luas daun tanaman gelombang cinta umur 8 MST di pembibitan lanjutan.

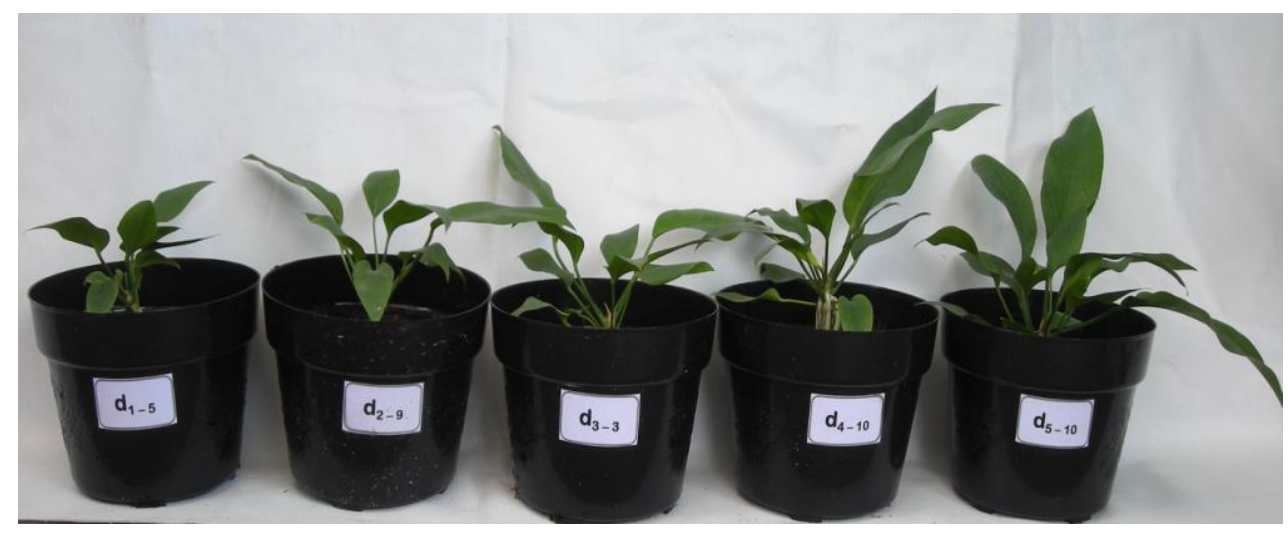

Gambar 3. Pertumbuhan tanaman gelombang cinta umur 8 MST di pembibitan lanjutan setelah diberikan pemupukan Petrovita.

mengandung unsur hara makro dan mikro mampu diserap dan menunjang proses metabolisme tubuh tanaman gelombang cinta. Hara yang bersumber dari pupuk daun Petrovita yang disemprotkan menjadi pemacu pertumbuhan tanaman gelombang cinta. Kandungan hara makro dan mikro pada pupuk daun Petrovita relatif tinggi, diantaranya $8,82 \% \mathrm{~N} ; 6,21 \% \mathrm{P}_{2} \mathrm{O}_{5}$; $6,47 \% \mathrm{~K}_{2} \mathrm{O} ; 1,89 \% \mathrm{~S}$; dan $0,03 \% \mathrm{Mg}$ yang dimanfaatkan oleh tanaman dalam mendukung tinggi tanaman. Begitu juga kandungan hara mikro meliputi unsur $\mathrm{Fe}, \mathrm{Cu}, \mathrm{Zn}, \mathrm{B}, \mathrm{Mo}, \mathrm{Mn}$, dan Co (Anonim, 2010).

Agustina (1990) menyatakan bahwa ketersediaan unsur hara akan mempengaruhi pertumbuhan tanaman dan banyaknya unsur hara yang diserap oleh tanaman sangat menentukan tingkat pertumbuhannya. Sutedjo (1995) juga 
menjelaskan bahwa unsur hara makro khususnya $\mathrm{N}, \mathrm{P}$ dan $\mathrm{K}$ merupakan hara yang penting bagi pertumbuhan tanaman. Fase vegetatif tanaman ternyata hara makro sangat memacu pertumbuhan tanaman muda untuk pembentukan organ-organ vegetatif. Unsur nitrogen berfungsi untuk pembentukan klorofil daun, penyusunan protein dan karbohidrat dalam proses fotosintesis. Fosfor berfungsi untuk proses pembelahan selsel meristematik dan perkembangan perakaran tanaman muda. Sedangkan kalium untuk mendukung proses metabolisme tubuh tanaman. Adanya peningkatan proses-proses tersebut menyebabkan meningkatnya pertumbuhan bagian-bagian tanaman dan terjadi pembentukan organ-organ tanaman sehingga secara keseluruhan meningkatkan pertumbuhan tanaman.

Berdasarkan Tabel 1 dan Gambar 1, 2 dan 3 nampaknya pertumbuhan tanaman gelombang cinta pada perlakuan $d_{1}$ lebih rendah dibanding perlakuan lainnya $\left(d_{2}, d_{3}, d_{4}\right.$, dan $\left.d_{5}\right)$. Hal ini diakibatkan pemberian pupuk daun Petrovita berhubungan dengan hara yang mampu disediakan dan diserap oleh tanaman gelombang cinta. Pemupukan dengan konsentrasi 0,05\% $\left(d_{1}\right)$ tersebut hanya menyediakan hara lebih sedikit meskipun analisis ragam perlakuan menunjukkan adanya pengaruh sangat nyata dalam meningkatkan pertumbuhan tanaman akibat aplikasi pupuk daun Petrovita. Begitu juga pertumbuhan yang baik pada perlakuan $d_{2}$ sampai $d_{5}$ ternyata juga membuktikan bahwa pemupukan Petrovita yang diberikan melalui daun mampu memberikan dukungan pertumbuhan yang baik pula.
Sebagai sumber nutrisi tambahan, nampaknya pupuk daun Petrovita malah memberikan peran yang signifikan dalam mendukung proses pertumbuhan meskipun tanaman juga memanfaatkan hara dari media pakis cacah dalam pot. Ini menunjukkan bahwa pemupukan daun pada tanaman gelombang cinta merupakan pemupukan yang efektif bagi pertumbuhannya. Endah (2002) menjelaskan bahwa salah satu dasar memupuk yang efektif adalah memperhatikan tujuan pemupukan dan memperhatikan media tanam apakah tergolong media yang miskin hara sehingga mempengaruhi pertumbuhan tanaman.

Penggunaan media tanam pakis cacah memang banyak digunakan untuk tanaman gelombang cinta meskipun tergolong haranya rendah dan banyak rongganya, sehingga tetap memerlukan pemupukan tambahan melalui medianya (pupuk akar). Sehubungan dengan pemenuhan hara bagi tanaman gelombang cinta, maka pemilihan pemupukan lewat daun menjadikan terpenuhinya kebutuhan hara. Rosmarkam dan Yuwono (2002), menyatakan bahwa pupuk daun dapat mengandung unsur makro dan mikro yang dapat langsung diserap oleh daun tanaman. Pemupukan melalui daun memberikan pengaruh yang lebih cepat terhadap tanaman dibanding lewat akar, meskipun kecepatan penyerapan hara juga dipengaruhi oleh status hara dalam tanah (media). Bila kadar hara dalam tanah (media) rendah maka penyerapan unsur hara melalui daun relatif lebih cepat dan sebaliknya.

Aplikasi pupuk daun Petrovita sebanyak 4 kali dengan interval 2 minggu sekali tersebut nampaknya berhasil memacu pertumbuhan bibit 
tanaman gelombang cinta. Konsentrasi mulai dari $0,05 \%\left(d_{1}\right)$ sampai konsentrasi $0,25 \%\left(d_{5}\right)$ secara fisiologis mampu memacu bibit tanaman tersebut seperti terlihat pada setiap pengamatan berupa tinggi tanaman, tinggi batang, jumlah daun, panjang daun, lebar daun, dan luas daun. Rendahnya kendala pemacuan pertumbuhan tanaman menggunakan pupuk daun juga menunjukkan upaya yang sederhana namun keberhasilannya cukup tinggi untuk tanaman gelombang cinta. Tentunya, selain jenis tanamannya yang responsif, juga kandungan hara pada jenis pupuknya menjadi hal yang diperhatikan. Kips (2007) menjelaskan bahwa daya tumbuh tanaman anthurim jenis jenmanii dan hookeri batang merah menempati posisi urutan ke-2 bila dibandingkan dengan jenis gelombang cinta dalam hal percepatan tumbuh, begitu juga tentang daya pacu tumbuh daunnya. Jenis gelombang cinta memang unggul dalam pertumbuhan daun yang lebih cepat, namun masih relatif rendah dalam hal pertumbuhan batang tongkol karena perlu di atas 6 daun untuk memunculkan tongkolnya.

Pemberian pupuk daun Petrovita termasuk efektif sebagai upaya pemeliharaan tanaman melalui pemupukan karena respon yang baik oleh tanaman gelombang cinta di pembibitan lanjutan berupa pertumbuhan. Hal ini terlihat semakin meningkat konsentrasi yang diberikan maka semakin terpacu pertumbuhannya, meskipun mutu daun (panjang dan lebarnya) masih relatif sama dengan perlakuan konsentrasi lainnya. Kondisi ini nampaknya juga bisa dilakukan dengan memperpendek aplikasi pemupukan kurang dari 2 minggu sekali dengan dosis dan konsentrasi yang sama. Selaras dengan upaya pemupukan tanaman hias, bahwa pupuk yang diberikan sebaiknya pupuk majemuk ( $\mathrm{N}, \mathrm{P}$, dan $\mathrm{K}$ ) yang penyediaannya haranya relatif lambat (slow release) untuk tanaman, dan apabila diberikan melalui akar dosisnya diberikan 2-3 bulan sekali dengan dosis sesuai anjuran dan besarnya tanaman, disamping itu juga perlu ditambahkan pupuk daun yang diberikan setiap 1 atau 2 minggu sekali (Dunia Flora, 2009).

Perlakuan $d_{4}$ (konsentrasi $0,2 \%$ ) yang secara umum tidak berbeda nyata dengan perlakuan $d_{5}$ (konsentrasi $0,25 \%$ ) dalam meningkatkan pertumbuhan bibit tanaman gelombang cinta tersebut, tersirat bahwa konsentrasi $0,2 \%$ merupakan aplikasi yang sesuai dengan pola penyerapan pupuk daun oleh daun tanaman gelombang cinta. Konsentrasi 0,2\% pun bermakna efisien selama diaplikasikan setiap 2 minggu sekali dibandingkan konsentrasi 0,25\% yang ditunjukkan dengan pertumbuhan yang masih sama akibat kedua konsentrasi tersebut diberikan dengan dosis dan interval yang sama, namun belum diketahui apabila dibedakan interval pemberiannya.

Beberapa penelitian menunjukkan bahwa pemupukan organik cair melalui daun memberikan pertumbuhan dan hasil yang lebih baik daripada melalui tanah (akar), namun pemupukan melalui daun harus memperhatikan konsentrasi dan dosis yang diaplikasikan. Semakin tinggi dosis yang diberikan maka kandungan hara untuk tanaman semakin tinggi, begitu juga semakin sering frekuensi aplikasi pupuk daun, maka kandungan hara juga semakin tinggi. Sedangkan pemberian dengan dosis yang berlebihan justru akan mengakibatkan timbulnya gejala kelayuan pada tanaman (Suwandi dan 
Nurtika, 1987; Hanolo,1997). Rizqiani et al. (2007) lebih lanjut menjelaskan bahwa pemilihan dosis yang tepat perlu diketahui dan dapat diperoleh melalui pengujian di lapangan sehingga sampai batas tertentu kombinasi antara dosis yang diberikan dengan frekuensi aplikasi pupuk daun menjadi faktor yang meningkatkan pertumbuhan dan hasil tanaman.

\section{KESIMPULAN DAN SARAN}

Kesimpulan penelitian ini adalah :

a. Pemberian pupuk daun lengkap Petrovita berpengaruh sangat nyata meningkatkan pertumbuhan tanaman gelombang cinta (Anthurium plowmanii) umur 8 MST pada pemeliharaan di pembibitan lanjutan berupa peningkatan tinggi tanaman, tinggi batang, jumlah daun, panjang daun, lebar daun, dan luas daun.

c. Pemberian pupuk daun Petrovita konsentrasi $0,2 \%$ atau $2 \mathrm{ml} \mathrm{I}^{-1}\left(\mathrm{~d}_{4}\right)$ merupakan perlakuan yang terbaik dan efisien meningkatkan pertumbuhan tanaman gelombang cinta di pembibitan lanjutan.

Saran dari hasil penelitian ini bahwa :

a. Meningkatkan pertumbuhan tanaman gelombang cinta di pembibitan lanjutan dapat memberikan pemupukan daun menggunakan Petrovita konsentrasi $0,2 \%$ dengan penyemprotan 2 minggu sekali.

b. Meningkatkan pertumbuhan tanaman gelombang cinta di pembibitan lanjutan agar menggunakan Petrovita konsentrasi 0,2\% tetapi dicoba dengan interval pemberiannya kurang dari 2 minggu (1 minggu, 5 hari, atau 3 hari sekali).

\section{UCAPAN TERIMA KASIH}

Ucapan terima kasih disampaikan kepada Koordinasi Perguruan Swasta (Kopertis) Wilayah $\mathrm{XI}$ yang telah membantu membiayai pelaksanaan penelitian bagi Dosen PTS Kopertis Wilayah XI Tahun 2011 ini sesuai Surat Keputusan Koordinator Kopertis XI untuk Dosen Universitas Muhammadiyah Palangkaraya Nomor 069/K11.A/KL/2011, tanggal 8 Agustus 2011.

\section{DAFTAR PUSTAKA}

Agustina, L., 1990. Nutrisi Tanaman. Rineka Cipta. Jakarta.

Anonim, 2007. Kunci Perawatan Anthurium : Ingat Keindahan Ada Pada Daun, Perlu Nutrisi Apa?. Tabloid Hobiku. Edisi 45/Tahun V. 3 - 16 Mei 2007. Hal.7

Anonim, 2008. Kocor Ya, Semprot Pun OK. Tabloid Agrobis ANTHURIUM. Edisi 21, 03 - 16 Juli 2008. Hal. 17.

Anonim, 2009. Statistik Pertanian Tanaman Pangan dan Hortikultura Kalimantan Tengah Tahun 2008. Dinas Pertanian dan Peternakan Provinsi Kalimantan Tengah. Palangka Raya.

Anonim, 2010. Pupuk Cair Lengkap Petrovita. PT. Petrokimia Kayaku. Gresik.

Bhermana A., R. Massinai, L. Rangin, dan M. Siahaan, 2009. Potensi Pengembangan Wilayah untuk Pertanian, Perkebunan, Hortikultura, dan Peternakan di Kalimantan Tengah. Balai Pengkajian Teknologi Pertanian Kalimantan Tengah. Palangka Raya.

Dunia Flora, 2009. Budidaya Anthurium. http://www.duniaflora.com/ mod.php? mod $=$ informasi\&op = viewinfo \& intypeid $=$ 3 \&infoid $=11$. Diakses tanggal 23 Maret 2011.

Endah H., J., 2002. Kiat Mengatasi Permasalahan Praktis : Membuat Tanaman Hias Rajin Berbunga. Agro Media Pustaka. Jakarta. 
Hanolo, W., 1997. Tanggapan Tanaman Selada dan Sawi Terhadap Dosis dan Cara Pemberian Pupuk Cair Stimulan. Jurnal Agrotropika 1(1):25-29.

Kips, 2007. Budidaya Anthurium Batang Merah Siap Menyalip Gelombang Cinta. http://kipsaint.com/isi/ budidaya- anthuriumbatang- merah- siapa- menyalipgelombang-cinta.html. Diakses tanggal 23 Maret 2011.

Mattjik, A. A. dan I.M. Sumertajaya. 2002. Perancangan Percobaan dengan Aplikasi SAS dan Minitab. Jilid I Edisi Ke-dua. IPB PRESS. Bogor.

Rizqiani, N.F., E. Ambarwati, dan N.W. Yuwono, 2007. Pengaruh Dosis dan Frekuensi Pemberian Pupuk Organik Cair Terhadap Pertumbuhan dan Hasil Buncis (Phaseolus vulgaris L.) Dataran Rendah. Jurnal IImu Tanah dan Lingkungan Vol. 7 No.1 (2007) p: $43-53$

Rosmarkam, A. dan N.W. Yuwono, 2002. Ilmu Kesuburan Tanah. Fakultas Pertanian Universitas Gadjah Mada. Yogyakarta.

Sitompul, S.M., dan B. Guritno, 1995. Analisis Pertumbuhan Tanaman. Gadjah Mada University Press. Yogyakarta.

Sutedjo, M. M., 1995. Pupuk dan Cara Pemupukan. Rineka Cipta. Jakarta.

Suwandi dan N, Nurtika, 1987. Pengaruh Pupuk Biokimia "Sari Humus" Pada Tanaman Kubis. Buletin Penelitian Hortikultura 15(20):213-218.

Waryoto. 2009. Efek Pemberian EM Terhadap Pertumbuhan Anthurium Gelombang Cinta (Anthurium plowmanii) Pada Media Campuran Pakis dan Kompos. Skripsi. Fakultas Keguruan dan IImu Pendidikan. Universitas Muhammadiyah Surakarta. Solo. 